\title{
ANALISIS KADAR KALSIUM (Ca) PADA CEKER AYAM KAMPUNG DAN CEKER AYAM POTONG DENGAN METODE SPEKTROFOTOMETRI SERAPAN ATOM
}

\author{
Nuradi $^{1}$, Evi Jayanti Budiman ${ }^{2}$ \\ ${ }^{1,2}$ Jurusan Analis Kesehatan Poltekkes Kemenkes Makassar
}

Koresponden : nuradi.poltekkes.mks@gmail.com

\begin{abstract}
ABSTRAK
Telah dilakukan penelitian tentang Analisis Kadar Kalsium (Ca) Pada Ceker Ayam Kampung Dan Ceker Ayam Potong Dengan Metode Spektrofotometri Serapan Atom. Penelitian ini bertujuan untuk mengetahui kadar kalsium $(\mathrm{Ca})$ pada ceker ayam kampung dan ceker ayam potong yang dianalisis dengan metode Spektrofotometri Serapan Atom. Dari hasil analisis kadar kalsium (Ca) pada ceker ayam kampung diperoleh hasil untuk ceker ayam kampung $1(1,31976 \mathrm{mg} / \mathrm{kg})$ dan ceker ayam kampung $2(1,20849 \mathrm{mg} / \mathrm{kg})$ dengan kadar kalsium rata-rata 1,26412 mg/kg. Pada ceker ayam potong, sampel ceker ayam potong $1(1,22166 \mathrm{mg} / \mathrm{kg})$ dan ceker ayam potong $2(1,17481 \mathrm{mg} / \mathrm{kg})$ dengan kadar kalsium rata-rata $1,198235 \mathrm{mg} / \mathrm{kg}$.
\end{abstract}

Kata kunci : Kalsium, Ceker Ayam Potong, Spektrofotometri Serapan Atom

\section{PENDAHULUAN}

Mutu gizi makanan seseorang dapat diperbaiki dengan mengkonsumsi makanan beranekaragam yang dapat memberikan sumbangan zat gizi yang cukup bagi tubuh, dengan adanya program penganekaragaman pangan merupakan cara yang penting untuk meningkatkan pengembangan gizi yang mencukupi pada tingkat daerah pedesaan, regional dan nasional. Disamping itu produksi pangan yang beranekaragam dapat dilakukan pengolahan dan distribusi pangan yang digunakan untuk memberikan keragaman pangan yang lebih besar pada makanan (Anisa, 2008).

Bahan makanan yang dikonsumsi tersebut berfungsi untuk mengatur proses metabolisme dalam tubuh serta memperbaiki jaringan tubuh yang rusak. Akan tetapi dengan perkembangan budaya manusia, tingkah laku mengkonsumsi makanan berubah pula. Kesadaran akan pentingnya makanan yang dapat memenuhi kebutuhan fisiologis juga semakin meningkat tidak saja sebagai penghilang rasa lapar, tetapi terutama sebagai pemenuhan fungsi fisiologis, rasa atau selera, tetapi juga harus mengandung zat-zat gizi seperti karbohidrat, protein, lemak, vitamin dan mineral (kalsium) (Almatsier, 2005).

Kalsium adalah salah satu mineral yang dibutuhkan oleh tubuh manusia. Menurut hasil penelitian, angka kecukupan rata-rata kalsium yang dianjurkan adalah 500-800 mg/orang tiap harinya dan pada usia menopause kira-kira 1000 mg/harinya (Gan, 1999). 
Kalsium merupakan unsur penting untuk kekuatan tulang dan gigi dan terdapat banyak pada sayuran berdaun hijau atau kacang-kacangan. Mengonsumsi vitamin D juga akan sangat membantu dalam penyerapan kalsium. Sedangkan untuk pemenuhan vitamin dan mineral, sangat mudah untuk dipenuhi oleh makanan yang berasal dari sayuran dan buah-buahan (Darningsih, S., 2010).

Bahan makanan yang mengandung kalsium salah satu diantaranya adalah ceker ayam. Ceker ayam sendiri merupakan bahan pangan yang mudah didapatkan diberbagai tempat, hanya saja masyarakat masih belum mengetahui manfaat ceker ayam yang dapat diolah menjadi bahan makanan. Menurut Biro Pusat Statistik (2002), populasi ayam di Indonesia sebanyak 716.131.200 ekor. Jumlah populasi ayam tersebut merupakan potensi mendapatkan bahan baku ceker ayam. Pemanfaatan ceker ayam selama ini masih rendah, yang dapat dilihat ceker ayam banyak dibuang dan menjadi limbah ternyata dapat dimanfaatkan sebagai keanekaragaman pangan yang memiliki kandungan zat gizi terutama pada kalsium (Anisa, 2008).

Dari uraian diatas peneliti telah melakukan penelitian tentang kadar kalsium $(\mathrm{Ca})$ pada ceker ayam kampung dengan ceker ayam potong dengan metode Spektrofotometri Serapan Atom

\section{METODE}

Penelitian ini merupakan penelitian observasi laboratorium. Penelitian dilaksanakan di Balai Besar Laboratorium Kesehatan Makassar pada bulan Mei 2017.
Sampel penelitian yang digunakan adalah ceker ayam kampung dan ceker ayam potong yang beredar di Kota Makassar.

Alat yang digunakan dalam penelitian ini yaitu : Cawan Porselin, Gelas Kimia (pyrex), Gelas Ukur (pirex), Kertas Saring, Labu ukur, Neraca Analitik, Penangas Listrik, Pipet Volume, Spektrofotometri Serapan Atom, Timbangan Digital/Analitik sedangkan bahan yang digunakan dalam penelitian ini ayaitu Asam Klorida, Asam nitrat (P), Aqua Destillata, Ayam kampung, Ayam potong, Kalsium karbonat.

Prosedur Penelitian

1. Pembuatan larutan sampel

Ceker ayam segar dicuci bersih, dipotong-potong kecil, lalu dikeringkan di bawah matahari langsung dan dipanaskan dioven kemudian dikelompokkan menjadi dua kelompok yaitu kelompok I ceker ayam kampung dan kelompok II ceker ayam potong. Ditimbang 5 gram masing-masing ceker ayam kampung dan ceker ayam potong, kemudian didestruksi dengan menggunakan tanur atau diabukan selama 2 jam pada suhu $550^{\circ} \mathrm{C}$ dan dibiarkan dingin. Abu dibasahkan dengan 10 tetes air dengan hati-hati, dengan menggunakan $\mathrm{HNO}_{3}$ pekat (1:1). Kelebihan $\mathrm{HNO}_{3} 100-110^{\circ} \mathrm{C}$, kemudian cawan porselin yang berisi sampel dimasukkan kembali kedalam tanur dan diabukan selama 1 jam pada suhu $500^{\circ} \mathrm{C}$, abu didinginkan dan dilarutkan dalam HCL (1:1) dan dipanaskan sampai mendidih, didinginkan kemudian disaring kedalam labu ukur $50 \mathrm{ml}$, lalu dipipet $5 \mathrm{ml}$ dan dimasukkan kedalam labu ukur $50 \mathrm{ml}$ 
kemudian dicukupkan dengan aquadest hingga tanda batas.

2. Analisis Kualitatif

Uji dengan Larutan Ammonium Oksalat yaitu dimasukkan $2 \mathrm{ml}$ larutan sampel kedalam tabung reaksi, ditambahkan $1 \mathrm{ml}$ ammonium oksalat. Jika hasil perubahan warnanya berwarna endapan putih kecoklatan berarti sampel mengandung kalsium. (Vogel, 1990).

3. Analisis Kuantitatif Dengan Spektrofotometri Serapan Atom

a. Pembuatan larutan Baku Pembanding Kalsium

Dilarutkan 0,25 gram kalsium karbonat dalam $20 \mathrm{ml}$ aquadest. lalu dimasukkan ke dalam labu tentukur $100 \mathrm{ml}$ kemudian diencerkan dengan air suling sampai tanda batas (1000 bpj). Dari larutan $1000 \mathrm{bpj}$ dipipet $10 \mathrm{ml}$ dimasukkan ke dalam labu ukur $100 \mathrm{ml}$ lalu dicukupkan volumenya dengan aquadest hingga tanda batas (100 bpj). Dipipet masingmasing $2 \mathrm{ml}, 4 \mathrm{ml}, 6 \mathrm{ml}, 8 \mathrm{ml}, 10$ $\mathrm{ml}$ dan $12 \mathrm{ml}$, kemudian dimasukkan ke dalam labu tentukur $100 \mathrm{ml}$ dan dicukupkan volumenya dengan aquadest hingga tanda batas hingga diperoleh larutan baku 2 bpj, 4 bpj, 6 bpj 8 bpj, 10 bpj, dan 12 bpj. Diukur serapannya dengan spektrofotometer serapan atom pada panjang gelombang maksimum 422,7 nm, kurva baku dibuat dengan cara memplotkan nilai serapannya terhadap konsentrasi larutan (bpj).

b. Pengukuran serapan kalsium dalam sampel

Ditimbang 5 gram sampel dimasukkan kedalam erlemeyer, ditambahkan aquadest sebanyak 25 ml dan $\mathrm{HNO}_{3} \quad 70 \% 5 \mathrm{ml}$,dan ditambahkan batu didih didektruksi sampai menghasilkan uap berwarna kuning kecoklatan dan didinginkan. Ditambahkan asam perklorat $60 \% 1 \mathrm{ml}$ dipanaskan kembali sampai menghasilkan uap putih sampai larutan jadi kuning jernih dan didinginkan kemudian disaring dengan kertas Whatman dan dicukupkan dengan aquabides sampai $50 \mathrm{ml}$. Diukur serapannya dengan spektrofotometer serapan atom pada panjang gelombang maksimum 422,7 nm.

Dari analisis serapan larutan baku dengan panjang gelombang maksimum, dibuat grafik antara serapan dan konsentrasi untuk kalsium. Dimana nilai serapan pada sumbu Y dan konsentrasi pada sumbu X. Kemudian ditarik garis diantara tititk untuk memperoleh persamaan garis lurus :

$$
\begin{aligned}
& \mathrm{Y}=\mathrm{a}+\mathrm{bx} \\
& \mathrm{a}=\text { konstanta } \\
& \mathrm{b}=\text { slope/ kemiringan }
\end{aligned}
$$

\section{HASIL}

Dari hasil penelitan yang dilakukan, maka diperoleh data tabel sebagai berikut : 
Tabel 1. Hasil analisis kualitatif Kalsium (Ca) pada ceker ayam kampong dan ceker ayam potong

\begin{tabular}{cccccc}
\hline No & Sampel & Pereaksi & Hasil & Pustaka & Ket \\
\hline 1. & $\begin{array}{c}\text { Ceker } \\
\text { ayam } \\
\text { kampung }\end{array}$ & $\begin{array}{c}\text { ammonium } \\
\text { oksalat }\end{array}$ & $\begin{array}{c}\text { endapan } \\
\text { putih } \\
\text { kecoklatan }\end{array}$ & $\begin{array}{c}\text { endapan } \\
\text { putih } \\
\text { kecoklatan }\end{array}$ & + \\
\hline 2. & $\begin{array}{c}\text { Ceker } \\
\text { ayam } \\
\text { potong }\end{array}$ & $\begin{array}{c}\text { ammonium } \\
\text { oksalat }\end{array}$ & $\begin{array}{c}\text { endapan } \\
\text { putih } \\
\text { kecoklatan }\end{array}$ & $\begin{array}{c}\text { endapan } \\
\text { putih } \\
\text { kecoklatan }\end{array}$ & + \\
\hline
\end{tabular}

Tabel 2. Hasil analisis kuantitatif Kalsium (Ca) pada ceker ayam kampung dan ceker ayam potong secara Spektrofotometri Serapan Atom

\begin{tabular}{cccc}
\hline Sampel & Absorben & $\begin{array}{c}\text { Kadar } \\
(\mathbf{m g} / \mathbf{k g})\end{array}$ & $\begin{array}{c}\text { Kadar } \\
\text { rata-rata } \\
(\mathbf{m g} / \mathbf{k g})\end{array}$ \\
\hline $\begin{array}{c}\text { Ceker } \\
\text { Ayam } \\
\text { Kampung 1 }\end{array}$ & 0,1827 & 1,31976 & \\
\cline { 1 - 1 } $\begin{array}{c}\text { Ceker } \\
\text { Ayam }\end{array}$ & 0,1751 & 1,20849 & \\
$\begin{array}{c}\text { Kampung 2 } \\
\text { Ceker } \\
\text { Ayam }\end{array}$ & 0,1760 & 1,26412 \\
$\begin{array}{c}\text { Potong 1 } \\
\text { Ceker } \\
\text { Ayam }\end{array}$ & 0,1728 & 1,17481 & \\
Potong 2 & & & \\
\hline
\end{tabular}

\section{PEMBAHASAN}

Kalsium merupakan unsur penting untuk kekuatan tulang dan gigi dan terdapat banyak pada sayuran berdaun hijau atau kacang-kacangan. Bahan makanan yang mengandung kalsium salah satu diantaranya adalah ceker ayam. Ceker ayam sendiri merupakan bahan pangan yang mudah didapatkan diberbagai tempat, hanya saja masyarakat masih belum mengetahui manfaat ceker ayam yang dapat diolah menjadi bahan makanan.

Dalam penelitian ini dilakukan penelitian tentang kadar kalsium dari ceker ayam potong dan ceker ayam kampung. Untuk menentukan kadar kalsium dalam ceker ayam potong dan ceker ayam kampung, maka dilakukan analisis kuantitatif yang didahului dengan melakukan uji kualitatif yang bertujuan untuk mengetahui lebih jelas ada tidaknya kandungan kalsium 
dalam ceker ayam tersebut. Uji kualitatif dilakukan dengan cara $2 \mathrm{ml}$ larutan sampel dimasukkan ke dalam tabung reaksi, ditambahkan $1 \mathrm{ml}$ ammonium oksalat. Terbentuk endapan putih kecoklatan menandakan adanya kalsium. (Vogel, 1990).

Analisis kuantitatif dilakukan dengan menggunakan Spektrofotometri Serapan Atom. Spektrofotometri serapan atom adalah suatu alat untuk menentukan beberapa logam dalam jumlah yang sangat kecil. Metode Spektrofotometri Serapan Atom berprinsip pada absorbsi cahaya oleh atom, atom-atom menyerap cahaya tersebut pada panjang gelombang tertentu, tergantung pada sifat unsurnya.

Sebelum dilakukan analisis kuantitatif, pertama-tama dibuat larutan sampel yaitu Ceker ayam segar dicuci bersih, kemudian didestruksi dengan menggunakan tanur atau diabukan selama 2 jam pada suhu $550^{\circ} \mathrm{C}$ dan dibiarkan dingin. Abu dibasakan dengan 10 tetes air dengan hati-hati, dengan menggunakan $\mathrm{HNO}_{3}$ pekat (1:1). Kelebihan $\mathrm{HNO}_{3}$ 100$110^{\circ} \mathrm{C}$, kemudian cawan porselin yang berisi sampel dimasukkan kembali kedalam tanur dan diabukan selama 1 jam pada suhu $500^{\circ} \mathrm{C}$, abu didinginkan dan dilarutkan dalam HCL (1:1) dan dipanaskan sampai mendidih, didinginkan kemudian disaring kedalam disaring kedalam labu ukur $50 \mathrm{ml}$, lalu dipipet $5 \mathrm{ml}$ dan dimasukkan kedalam labu ukur $50 \mathrm{ml}$

\section{KESIMPULAN}

Berdasarkan hasil penelitian yang telah dilakukan maka dapat kemudian dicukupkan dengan aquadest hingga tanda batas. Diukur serapannya dengan spektrofotometer serapan atom pada panjang gelombang maksimum $422,7 \mathrm{~nm}$.

Analisis kuantitatif dilakukan dengan menggunakan spektrofotometer pada panjang gelombang maksimum. Pengukuran dilakukan pada daerah visible yaitu pada panjang gelombang 422,7 nm. Dari hasil analisis kadar kalsium $(\mathrm{Ca})$ pada ceker ayam kampung diperoleh hasil untuk ceker ayam kampung 1 $(1,31976 \mathrm{mg} / \mathrm{kg})$ dan ceker ayam kampung $2(1,20849 \mathrm{mg} / \mathrm{kg})$ dengan kadar kalsium rata-rata 1,26412 $\mathrm{mg} / \mathrm{kg}$. Pada ceker ayam potong, sampel ceker ayam potong 1 (1,22166 $\mathrm{mg} / \mathrm{kg}$ ) dan ceker ayam potong 2 $(1,17481 \mathrm{mg} / \mathrm{kg})$ dengan kadar kalsium rata-rata $1,198235 \mathrm{mg} / \mathrm{kg}$.

Dari hasil penentuan kadar kalsium ceker ayam potong dan ceker ayam kampung menunjukkan bahwa sampel ceker ayam kampung memiliki kadar kalsium rata-rata 1,26412 $\mathrm{mg} / \mathrm{kg}$, sedangkan sampel ceker kampung memiliki kadar kalsium ratarata $1,198235 \mathrm{mg} / \mathrm{kg}$. Hal ini menunjukkan bahwa ada perbedaan yang nyata antar sampel ceker ayam potong dengan ceker ayam kampung. Dengan demikian dapat dikatakan bahwa proses pengolahan ceker ayam potong dan ceker ayam kampung berpengaruh terhadap kandungan kalsiumnya

disimpulkan bahwa Kadar kalsium (Ca) pada ceker ayam kampung diperoleh kadar rata-rata 1,26412 
$\mathrm{mg} / \mathrm{kg}$ dan kadar rata-rata kalsium (Ca) pada ceker ayam potong yaitu $1,198235 \mathrm{mg} / \mathrm{kg}$.

\section{SARAN}

1. Disarankan untuk melakukan penelitian kadar kalsium yang

\section{DAFTAR PUSTAKA}

Almatsier, S., 2005, Prinsip Dasar Ilmu Gizi, PT. Gramedia Pustaka Utama, Jakarta.

Anisa, 2008. Pengolahan Caker Menjadi Tepung . Capter 1-2. Universitas Sumatra Utara.

Atmasier, S., 2003. Prinsip Dasar Ilmu Gizi. Gramedia Pustaka Utama, Jakarta.

Bender, G.T. 1987. Principal of Chemical Instrumentation. Philadhelphia: W.B.. Sounders Company.

Cahyono P.H., 2012. Makalah Gizi Kalsium. Universitas Negri Yokyakarta. Fakultas Keolaragaan. Yogyakarta.

Darningsih S. Dkk., 2010. Hubungan Kalsium Dengan Ricketsia Osteomalasa dan Osteoarthritis. Makala Biologi, Jakarta.

Gan, S. 1999. Farmakologi dan Terapi. Edisi IV. Jakarta: Fakultas Kedokteran Universitas Indonesia. terdapat pada ceker ayam dengan jenis ayam yang berbeda.

2. Disarankan agar dilanjutkan penelitian mengenai kadar gizi lainya yang terdapat dalam ceker ayam.

Gandjar, I. G, 2009, Kimia Farmasi Analisa, Pustaka Belajar. UGM, Yogyakarta

Harmita. 2004. Petunjuk Pelaksanaan Validasi Metode dan Cara Perhitungannya. Review Artikel. Majalah Ilmu Kefarmasian. Vol 1 (3): 117-135.

John M.P., 2004. Nutritional rickets: deficiency of vitamin D, calcium, or both? American Journal of Clinical Nutrition, Vol. 80, No. 6, 1725S-1729S, December 2004.

Mahan,L.K \& Stump, 2000. Food, Nutrition and Diet Therapy. Pensylvania. Saunders.

Mulja, M. 1990. Analisis Instrumental. Airlangga University Press, Surabaya

Rohman, Sumantri. 2007. Analisis Makanan. Gadjah Mada University Press.

Sumarianto dan Nurhaida. 2009. Kamus Kedokteran. Cetakan pertama. Jakarta: Ade Putra 
Lampiran 1. Hasil perhitungan persamaan garis regresi linear Kalsium (Ca) dengan menggunakan Spektrofotometri Serapan Atom

\begin{tabular}{|c|c|c|c|c|c|}
\hline $\begin{array}{c}\mathrm{N} \\
\mathrm{o}\end{array}$ & $\mathrm{X}$ & $\mathrm{Y}$ & $\mathrm{Xy}$ & $\mathrm{x}^{2}$ & $\mathrm{y}^{2}$ \\
\hline 1 & 2 & 0,3435 & 0,687 & 4 & 0,1179 \\
\hline 2 & 4 & 0,6825 & 2,73 & 16 & 0,4658 \\
\hline 3 & 8 & 1,1798 & 9,4384 & 64 & 1,3919 \\
\hline 4 & 10 & 1,4064 & 14,064 & 100 & 1,9779 \\
\hline 5 & 12 & 1,7682 & 21,2184 & 144 & 3,1265 \\
\hline $\begin{array}{c}\mathrm{n}= \\
5\end{array}$ & $\begin{array}{c}\sum \mathrm{x} \\
=\end{array}$ & $\begin{array}{c}\sum \mathrm{y}=5, \\
36\end{array}$ & $\begin{array}{c}\sum \mathrm{xy}=48, \\
14\end{array}$ & $\begin{array}{c}\sum \mathrm{x}^{2}=3 \\
28\end{array}$ & $\begin{array}{c}\sum \mathrm{y}^{2}=7, \\
08\end{array}$ \\
\hline
\end{tabular}

Persamaan Garis regresi : $\mathrm{Y}=\mathrm{a}+\mathrm{bx}$

Dimana :

$$
\begin{aligned}
& \mathrm{Y}=\text { Serapan } \\
& \mathrm{X}=\text { Konsentrasi }(\mathrm{ppm}) \\
& \mathrm{a}=\text { Konstanta } \\
& \mathrm{b}=\text { Slope } / \text { kemiringan } \\
& \mathrm{n}=\text { Perlakuan }
\end{aligned}
$$

Berdasarkan rumus :

$$
\begin{aligned}
\mathrm{a} & =\frac{\sum y-b\left(\sum x\right)}{n} \\
\mathrm{~b} & =\frac{n\left(\sum x y\right)-\left(\sum x\right)\left(\sum y\right)}{n\left(\sum x^{2}\right)-\left(\sum x\right)^{2}} \\
\mathrm{~b} & =\frac{5(48,1378)-(36)(5,3804)}{5(328)-(36)^{2}} \\
& =\frac{240,689-193,6944}{1640-1296} \\
& =\frac{46,9946}{344} \\
& =0,1366 \\
\mathrm{a} & =\frac{\sum y-b\left(\sum x\right)}{n} \\
& =\frac{5,3804-0,1366(36)}{5} \\
& =\frac{5,3804-4,9176}{5} \\
& =0,09256
\end{aligned}
$$

Jadi persamaan garis regresinya adalah :

$\mathrm{y}=\mathrm{a}+\mathrm{bx}$

$y=0,09256+0,1366 x$ 


\title{
Lampiran 2 : Contoh Perhitungan Kadar Kalsium (Ca) Pada Ceker Ayam Kampung
}

\author{
1. Sampel : Ceker Ayam Kampung 1 \\ Serapan : :0,1827 \\ Berat Sampel : $: 5$ gram \\ Volume Sampel \\ $: 10 \mathrm{ml}$
}

Dari rumus diatas sehingga diperoleh hasil sebagai berikut :

$$
\begin{aligned}
\mathrm{Y} & =0,09256+0,1366 \mathrm{x} \\
\mathrm{X} & =\frac{Y \sim(0,09256)}{0,1366} \\
& =\frac{0,1827-0,09256}{0,1366} \\
& =0,65988 \mathrm{mg} / \mathrm{L}
\end{aligned}=\frac{0,09014}{0,1366}
$$

$$
\begin{aligned}
\text { Kadar Kalsium } & =\frac{\text { konsentrasi } x \text { Volume sampel }}{\text { berat sampel }(\mathrm{kg})} \\
& =\frac{0,65988 \frac{\mathrm{mg}}{\mathrm{L}} \times 0,01 \mathrm{~L}}{0,005 \mathrm{~kg}} \\
& =1,31976 \mathrm{mg} / \mathrm{kg}
\end{aligned}
$$

